\title{
Analisis Sitiran terhadap Skripsi Jurusan Kartografi dan Penginderaan Jauh Fakultas Geografi Tahun 2005 dan Ketersediaannya di Perpustakaan Fakultas Geografi UGM
}

\author{
Purwani Istiana*, Sri Rohyanti Zulaikha**
}

\begin{abstract}
The library needs to know the kind of literature mostly read, and whether those literature are willable in the library. This matter will be used for adding the collection in order to meet the needs of the users. The research aims to discuss citation analysis of Literature Cited in Scription of Department of Cartography and Remote Sensing on the Faculty of Geography at Gadjah Mada University 2005. The purpose of the research is, to know the kind of literature cited in scription of the Department of Cartography and Remote Sensing on the Faculty of Geography, to find out the dominant literature cited, to identify the language literature cited, and to know the availability of the literature cited in library of Faculty of Geography. The subject of the research is the scription of the Department of Cartography and Remote Sensing on the Faculty of Geography. The object of research are all citations in references of the scriptions, numbering at 2554 citations. The method of the data collection used is citation analysis. The Analysis of data is based on the percentage provided on the table. The result shows that the kind of literature cited in the scription of the Department of Cartography and Remote Sensing on the Faculty of Geography 2005 is book 1686 citations (66\%), scription 295 citations $(11,56 \%)$, internet source 138 citations $(5,41 \%)$, journal or magazine 115 citations $(4,51 \%)$, thesis 95 citations $(3,72 \%)$, paper 80 citations $(3,14 \%)$, research report 51 citations $(2 \%)$, proceeding 36 citations $(1,42 \%)$, newspaper 26 citations $(1,02 \%)$, disertation 18 citations $(0,71 \%)$, field work report and pidato 13 citations $(0,51 \%)$. It also describes that the literature in Indonesian languange had been more often cited than that in English. It is 1759 citations $(68,9 \%)$ versus 794 citations $(31.1 \%)$. The last, the level of the avalibility of the literatu re cited is found that $71,68 \%$ where available in the library and the other $28,32 \%$ where not available.
\end{abstract}

Keywords : citation, citation analysis, collection availability

\section{ABSTRAK}

Perpustakaan perlu mengetahui literatur yang sering dibaca, dan juga literatur itu akan tersedia di perpustakaan. Masalah ini akan digunakan untuk penambahan koleksi agar sesuai dengan kebutuhan pengguna. Penelitian ini bertujuan untuk mendiskusikan analisis sitiran dari literatur yang disitir dalam Skripsi jurusan Kartografi dan Penginderaan Jauh di Fakultas Geogarfi Universitas Gadjah Mada tahun 2005. Tujuan penelitian ini adalah untuk mengetahui jenis / macam literatur yang disitir dalam skripsi jurusan Kartografi dan Penginderaan Jauh pada Fakultas Geografi, untuk menemukan literatur yang sering disitir, untuk mengidentifikasikan bahasa literatur yang disitir, dan untuk mengetahui ketersediaan literatur yang disitir di perpustakaan fakultas Geografi. Subjek penelitian ini adalah skripsi dari jurusan Kartografi dan Penginderaan Jauh Fakultas Geografi. Objek penelitiannya adalah semua sitasi dalam daftar pustaka skripsi, sekitar 2554 sitasi. Metode pengumpulan data menggunakan analisis sitiran. Analisis data didasarkan pada prosentase yang diberikan melalui tabel data. Hasilnya menunjukkan bahwa jenis atau macam literatur yang disitir dalam skripsi jurusan Kartografi dan Penginderaan Jauh pada Fakultas Geografi adalah buku 1686 sitasi (66\%), skripsi 295 sitasi $(11,56 \%)$, sumber internet 138 sitasi $(5,41 \%)$, jurnal atau majalah 115 sitasi $(4,51 \%)$, tesis 95 sitasi $(3,72 \%)$, makalah 80 sitasi $(3,14 \%)$, laporan penelitian 51 sitasi $(2 \%)$, prosiding 36 sitasi $(1,42 \%)$, surat kabar 26 sitasi $(1,02 \%)$, disertasi 18 sitasi $(0,71 \%)$, laporan kerja lapangan dan pidato 13 sitasi $(0,51 \%)$. Hal itu juga menggambarkan bahwa literatur berbahasa Indonesia lebih banyak disitir daripada sitasi berbahasa Inggris. Ada 1759 sitasi berbahasa Indonesia $(68,9 \%)$ berbanding 794 sitasi berbahasa Inggris $(31.1 \%)$. Terakhir, tingkat ketersediaan literatur yang disitir ditemukan bahwa 71,68\% tersedia di perpustakaan dan lainnya 28,32\% tidak tersedia.

Kata kunci: sitasi, analisis sitasi, ketersediaan koleksi 


\section{PENDAHULUAN}

Salah satu kegiatan penelitian yang dilakukan di perguruan tinggi adalah penelitian guna menyelesaikan tugas akhir yang selanjutnya dituangkan dalam bentuk karya akhir skripsi, Dalam buku Pedoman Penulisan Skripsi Fakultas Geografi (2005:1) disebutkan bahwa skripsi adalah karya ilmiah seorang mahasiswa berupa paparan tulisan hasil penelitian yang membahas suatu masalah dalam bidang ilmu sesuai pada program studi yang sedang ditempuh dengan menggunakan kaidah ilmiah yang berlaku untuk mengakhiri materi ajar dalam kurikulum program kesarjanaan. Mahasiswa dalam penulisan skripsi membutuhkan sumber informasi untuk mendukung tulisannya. Selanjutnya sumber informasi yang digunakan dicantumkan dalam daftar pustaka. Literatur yang disitir dalam skripsi mahasiswa adalah yang isinya terkait dengan subyek kajian skripsi yang dibuatnya. Andriani (2002:29) menyatakan alasan utama penulis menyitir suatu karya ialah untuk mengidentifikasi metode dan peralatan yang digunakan, memperkuat temuan, menerangkan konsep atau ide, menerangkan suatu definisi, teori, istilah dan untuk pembanding.

Surata (1997:1) mengungkapkan bahwa keberadaan literatur dalam kegiatan penelitian mempunyai peranan yang dibutuhkan. Sebagian dari kegagalan suatu penelitian disebabkan antara lain keterbatasan literatur sebagai sumber informasi. Mahasiswa dalam menyelesaikan kegiatan penelitiannya berharap perpustakaan dapat menyediakan literatur pendukung yang diperlukan. Perpustakaan Fakultas Geografi sebagai unit penunjang kegiatan penelitian, berupaya untuk mengevaluasi diri apakah literatur yang dibutuhkan oleh pengguna telah tersedia di perpustakaan. Kebutuhan pengguna menyangkut, jenis literatur, bahasa, pengarang, judul, tempat terbit, penerbit dan tahun terbit literatur. Salah satu kegiatan yang sulit sekaligus penting di dalam suatu perpustakaan adalah kegiatan pemilihan buku dan bahan lain yang akan disediakan di perpustakaan untuk dimanfaatkan pemakai.

Upaya yang dapat dilakukan untuk mengetahui literatur yang dibutuhkan pengguna adalah melalui kajian analisis sitiran terhadap karya tulis yang dihasilkan oleh pengguna perpustakaan. Smith dalam Yulia (1995:20) mengatakan sitiran muncul setelah informasi digunakan, maka keberadaannya tidak dapat disangkal. Sulistyo-Basuki (2006) menyebutkan sitiran adalah informasi literatur yang dimuat dalam referens. Sedangkan referens adalah acuan atau daftar kepustakaan, lazimnya tercetak pada bagian bawah setiap halaman sering disebut catatan kaki.

Pertanyaan dalam penelitian ini adalah:

1. Jenis literatur apa saja yang disitir dalam skripsi Jurusan Kartografi dan Penginderaan Jauh Fakultas Geografi UGM dan jenis literatur apa yang dominan disitir?

2. Bahasa literatur apa yang disitir dalam skripsi Jurusan Kartografi dan Penginderaan Jauh Fakultas Geografi UGM tahun 2005?

3. Bagaimana ketersediaan literatur yang disitir tersebut di Perpustakaan Fakultas Geografi UGM? 
Kajian dalam penelitian ini dibatasi hanya pada kajian analisis sitiran terhadap skripsi Jurusan Kartografi dan Penginderaan Jauh Fakultas Geografi UGM tahun 2005.

Penelitian ini didasari atas beberapa asumsi yaitu :

1. Semua literatur yang disitir benar-benar dipergunakan dalam penulisan skripsi.

2. Semua literatur yang dipergunakan dalam penulisan skripsi benar-benar dicantumkan dalam daftar pustaka atau bibliografi.

3. Setiap sitiran bernilai sama untuk setiap jenis literatur.

4. Literatur yang sering disitir atau banyak disitir lebih bernilai dibandingkan literatur yang jarang atau tidak pernah disitir.

5. Semua literatur yang disitir dalam penulisan skripsi diasumsikan dipinjam dari perpustakaan, selama dokumen tersebut ada di perpustakaan.

Keberhasilan perpustakaan dalam memberikan jasa layanan perpustakaan salah satunya ditentukan oleh bagaimana kegiatan pemilihan sumber-sumber informasi yang disediakan benar-benar relevan dengan kebutuhan pemakai. Dengan mencermati daftar sitiran dalam daftar pustaka dan bagaimana ketersediaannya di perpustakaan, diharapkan dapat menjadi pertimbangan bagi perpustakaan dalam kegiatan pengembangan koleksinya.

\section{Bibliometrika Bagi Perpustakaan}

Sulistyo-Basuki (2002:4) menyebutkan bahwa pada dasarnya bibliometrika terbagi atas dua kelompok besar yaitu kelompok yang mengkaji distribusi publikasi dan kelompok yang membahas analisis sitiran/sitasi (citation analysis). Kelompok pertama, tiga dasar bibliometrika yaitu dalil Lotka yang menghitung distribusi produktivitas berbagai pengarang, dalil Zipf yang memberi peringkat kata dan frekuensi dalam literatur dan hukum Bradford yang mendeskripsikan dokumen (biasanya majalah) dalam disiplin tertentu.

Aplikasi bibliometrika yang banyak manfaatnya bagi perpustakaan adalah :

1. Identifikasi literatur inti.

2. Mengidentifikasi arah gejala penelitian dan pertumbuhan pengetahuan pada berbagai disiplin ilmu yang berlainan.

3. Menduga keluasan literatur sekunder.

4. Mengenali pemakai berbagai subjek.

5. Mengenali kepengarangan dari arah gejalanya pada dokumen berbagai subjek.

6. Mengukur manfaat SDI dan restropektif.

7. Meramalkan arah gejala perkembangan masa lalu, sekarang dan mendatang.

8. Mengidentifikasi majalah inti dalam berbagai disiplin ilmu.

9. Merumuskan garis haluan pengadaan berbasis kebutuhan yang tepat dalam batas anggaran belanja.

10. Mengembangkan model eksperimental yang berkorelasi atau melewati model yang ada.

11. Menyusun garis haluan penyiangan dan penempatan dokumen di rak secara tepat. 
12. Memprakasai sistem jaringan aras ganda yang efektif.

13. Mengatur arus masuk informasi dan komunikasi.

14. Mengkaji keusangan dan penyebaran literatur ilmiah.

15. Meramalkan produktivitas penerbit, pengarang, organisasi, negara atau seluruh disiplin.

16. Mendisain pengolahan bahasa atomatis untuk auto-indexing, auto-abstracting dan auto-classification.

17. Mengembangkan norma pembakuan. (Sulistyo-Basuki, 2002:8)

\section{Analisis Sitiran}

Menurut ALA Glosasary of Library and Information Science dalam Rupadha (1996:17), disebutkan bahwa citation adalah suatu catatan yang menunjuk kepada suatu karya yang bagian-bagian dari isinya telah dikutip, atau yang menunjuk kepada beberapa sumber yang berwenang untuk suatu pernyataan atau masalah. Reitz (2006) menyebutkan citation merupakan acuan tertulis dari sebuah karya atau bagian sebuah karya (dapat berupa buku, artikel, disertasi, laporan, komposisi musik dan sebagainya) yang dihasilkan oleh pengarang, penyunting, komposer dan sebagainya, yang secara jelas mengidentifikasi sesuatu dokumen, di mana karya itu diperoleh. Disebutkan pula bahwa sering tidaknya suatu karya disitir kadang-kadang dianggap sebagai ukuran penting tidaknya sebuah literatur. Andriani (2002:29) menyatakan sitiran adalah pernyataan yang diterima suatu dokumen dari dokumen lain. Diungkapkan pula bahwa sitiran mengarah pada karya yang diacu yang dilakukan oleh penulis sesudah karya yang diacu diterbitkan.

Sitiran berhubungan dengan dua jenis data, yaitu data yang dikutip dan data yang mengutip. Data yang dikutip merupakan sebuah dokumen atau unsur yang menunjukan unit sumber, sehingga selalu lebih tua daripada dokumen yang mengutip. Data yang mengutip merupakan unit penerima, karena itu selalu lebih muda usianya daripada dokumen yang dikutip.

Alasan mengapa penulis menyitir karya terdahulu berbeda satu dengan yang lain. Disebutkan oleh Andriani (2002:32) mengapa pengarang menyitir karya sebelumnya :

1. Sebagai bahan latar belakang.

2. Memberitahu pembaca tentang penelitian yang pernah dilakukan.

3. Memperkuat atau mendukung sebuah temuan.

4. Mengidentifikasi metode dan peralatan.

5. Menerangkan konsep dan ide.

6. Menerangkan suatu definisi, teori atau istilah.

7. Menunjukkan adanya larya lain yang bertentangan.

8. Menunjukkan data dari penelitian sebelumnya.

9. Sebagai bahan pembanding.

10. Membantu menemukan kembali informasi yang dipakai dan menunjukkan karya yang pernah dipublikasikan.

Adanya sitiran menunjukkan adanya hubungan suatu karya yang menyitir dengan 
karya lain yang disitir. Karya ilmiah yang baru akan selalu mengacu pada karya ilmiah terdahulu. Dan idealnya karya yang disitir benar-benar mendukung karya yang menyitir.

Penggunaan analisis sitiran dalam pengembangan koleksi dinyatakan oleh MacGrill dan Corbin dalam Surata (1997:24) didasarkan pada asumsi bahwa bahan yang sering disitir atau banyak disitir lebih bernilai dibandingkan bahan yang jarang disitir atau tidak pernah disitir.

Bahan/literatur yang banyak disitir berarti pula bahan/literatur tersebut penting bagi pemakai atau dengan kata lain pemakai membutuhkan literatur tersebut. Sehingga keberadaan literatur tersebut perlu dicatat atau diperhatikan oleh perpustakaan, sedapat mungkin ketersediaannya dapat dipenuhi. Sesuai apa yang dinyatakan Septiyantono (2003:77) bahwa sumber-sumber informasi harus dikembangkan sebaik-baiknya sesuai dengan kondisi dan kebutuhan masyarakat yang dilayani.

Bila analisis sitiran digunakan sebagai bahan masukan untuk membantu pustakawan dalam merencanakan dan menentukan bahan pustaka yang akan disediakan, maka data sitiran yang digunakan diambil dari sumber atau karya yang ditulis oleh pemakai perpustakaan yang bersangkutan. Di perpustakaan perguruan tinggi data dapat diambil dari skripsi, tesis, disertasi, laporan penelitian dan sejenisnya, Smith dalam Yulia (1995:22).

Penggunaan teknik analisis sitiran terbagi dalam kategori sebagai berikut (SulistyoBasuki, 2006:6) :
1. Pengembangan koleksi, kajian pemakai. Analisis sitiran digunakan untuk merumuskan kebijakan langganan majalah dengan menilai majalah berdasarkan berapa kali sebuah majalah disitir. Digunakan pula untuk penghentian langganan berdasarkan sering tidaknya sebuah majalah disitir. Analisis sitiran mengkaji pula nilai relatif dari berbagai jenis dokumen terhadap berbagai kategori pemakai.

2. Temu balik informasi.

Analisis sitiran digunakan untuk mengembangkan pengganti dokumen, hubungan kata kunci-dokumenpemakai dan strategi penelusuran, identifikasi berbantuan komputer mengenai artikel yang menyitir dan akses terhadap literatur interdisipliner.

3. Pengembangan dan pertumbuhan subjek dan literatur subjek.

Produktivitas pengarang dan pengaruhnya terhadap pengarang lain diukur melalui sitiran. Pasangan sitiran dan ko-sitiran digunakan untuk mengkaji struktur pertumbuhan ilmiah sebuah bidang/subjek dan membuat peta batas-batas berbagai subjek.

4. Kajian historis dan penelitian yang sedang berlangsung.

Melacak pengembangan sebuah subjek melalui kaidah waktu, densitas dan konteks sitiran serta menggunakan jaringan sitiran sebagai ukuran untuk menilai antar hubungan dan pengaruh berbagai pengarang beserta karya mereka. 
5. Pola komunikasi penelitian.

Kajian dampak isolasi karena kendala bahasa, jarak dan ketersediaan literatur ilmiah.

6. Untuk menghitung paro hidup sebuah bidang ilmu.

\section{METODE PENELITIAN}

Penelitian ini bersifat deskriptif yaitu ingin menggambarkan jenis literatur dan literatur yang dominan disitir, bahasa literatur serta ketersediaan literatur yang disitir dalam skripsi Jurusan Kartografi dan Penginderaan Jauh, Fakultas Geografi UGM tahun 2005. Penelitian ini menggunakan seluruh populasi skripsi Jurusan Kartografi dan Penginderaan Jauh tahun 2005 sebanyak 79 skripsi.

Metode pengumpulan data yang dipergunakan dalam penelitian ini adalah metode analisis sitiran. Dalam penelitian ini data sitiran yang digunakan adalah sitiran yang terdapat dalam daftar pustaka setiap skripsi, yang nantinya akan dibuatkan tabel. Tahap-tahap yang akan penulis lalui sebagai berikut :

1. Mencari data ke Perpustakaan Fakultas Geografi UGM, skripsi Jurusan Kartografi dan Penginderaan Jauh tahun 2005.

2. Berdasarkan nomor pánggil skripsi tersebut, mengambil skripsi dari susunan rak.

3. Membuat fotokopi daftar pustaka dan halaman sampul dari setiap skripsi.

4. Selanjutnya data sitiran dica tat, meliputi nomor skripsi, pengarang, judul buku/ artikel, tahun terbit, tempat terbit, penerbit, jenis literatur, bahasa literatur dan nama jurnal.

5. Mencocokkan data sitiran yang telah dicatat dengan data koleksi yang ada di Perpustakaan Fakultas Geografi UGM, untuk memperoleh data ketersediaannya di perpustakaan.

Setelah seluruh data dikumpulkan, maka peneliti melakukan analisis data menggunakan prosentase. Tahapan yang dilakukan peneliti dalam menganalisis data untuk menjawab pertanyaan dalam penelitian adalah sebagai berikut :

1. Meneliti kelengkapan data yang telah diisi pada tabel lembar kerja Microsoft Excel.

2. Mengelompokkan data berdasarkan jenis literatur.

3. Menghitung jumlah sitiran yang diterima oleh masing-masing jenis literatur.

4. Penentuan peringkat jenis literatur yang paling banyak disitir.

5. Hasil penentuan peringkat jenis literatur dengan perhitungan prosentase dan disajikan dalam bentuk tabel.

6. Pengelompokkan berdasarkan jenis literatur akan terlihat jelas jenis literatur apa yang dominan disitir.

7. Mengelompokkan data berdasarkan bahasa literatur.

8. Penentuan peringkat bahasa literatur yang paling banyak disitir.

9. Hasil penentuan peringkat bahasa literatur dilakukan penghitungan 
prosentase dan disajikan dalam bentuk tabel.

10. Selanjutnya dari masing-masing tabel dilakukan analisis secara deskriptif.

11. Semua data sitiran dicocokkan dengan data koleksi di Perpustakaan Fakultas Geografi UGM, untuk mengetahui keberadaannya di perpustakaan.

12. Dilakukan penghitungan koleksi yang tersedia dan tidak tersedia di perpustakaan.

13. Hasil penghitungan diprosentase dan disajikan dalam bentuk tabel.

\section{HASIL DAN PEMBAHASAN}

Dari seluruh skripsi ( 79 skripsi) Jurusan Kartografi dan Penginderaan Jauh Fakultas Geografi tahun 2005 , diperoleh sebanyak 2.554 sitiran. Dalam penelitian ini, untuk olah data dan analisis data 1 (satu) sitiran tidak digunakan karena data tidak cukup lengkap. Total sitiran yang dipergunakan dalam penelitian ini sebanyak 2.553 sitiran.

\section{Jenis Literatur yang Disitir}

Jenis literatur yang disitir dalam skripsi mahasiswa Fakultas Geografi Jurusan Kartografi dan Penginderaan Jauh tahun 2005 terdiri dari berbagai jenis. Dalam penelitian ini jenis literatur dikelompokkan atas buku, skripsi, sumber internet, jurnal/majalah, tesis, makalah, laporan penelitian, proseding, surat kabar, disertasi dan laporan praktek kerja serta pidato. Perolehan jumlah sitiran untuk masingmasing jenis literatur dapat dilihat pada tabel 1.

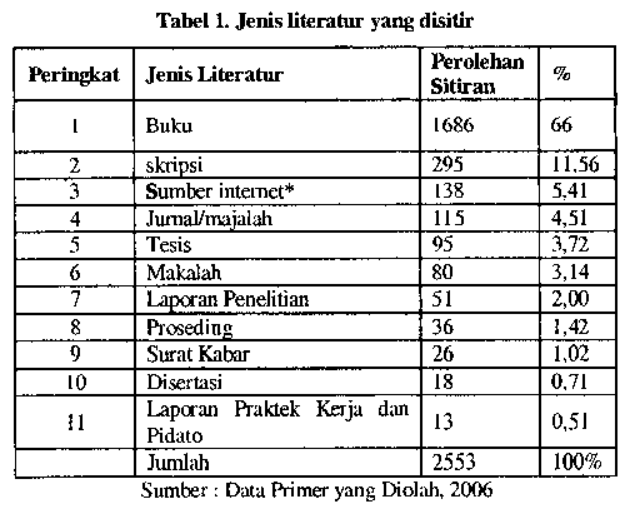

Tabel 2. Bahasa Literatur

\begin{tabular}{|l|l|l|l|}
\hline No. & Bahasa & Jumlah Sitiran & $\%$ \\
\hline 1 & Indonesia & 1759 & 68,90 \\
\hline 2 & Inggris & 794 & 31,10 \\
\hline Jumlah & 2553 & $100 \%$ \\
\hline
\end{tabular}

Sumber : Data Primer yang Diolah, 2006.

Tabel 3. Ketersediaan Literatur yang Disitir di Perpustakaan

\begin{tabular}{|l|l|l|l|}
\hline \multicolumn{1}{|c|}{ No. } & Jumlah Sitiran & $\%$ & Ketersediaan \\
\hline 1. & 1830 & 71,68 & tersedia \\
\hline 2. & 723 & 28,32 & tidak tersedia \\
\hline Jumlah & 2553 & $100 \%$ & \\
\hline \multicolumn{2}{|c|}{ Sumber : Data Primer yang Diolah, 2006. }
\end{tabular}

Sumber internet dalam penelitian ini dikelompokan tersendiri, karena dalam kenyataannya mahasiswa cukup banyak menggunakan informasi yang bersumber dari internet. Terkadang sitiran yang bersumber dari internet tidak mudah diidentifikasi apakah tergolong jenis buku, jurnal, makalah dan sebagainya, sehingga peneliti berkesimpulan untuk mengelompokan tersendiri. Penulis menyadari bahwa sumber internet bukanlah termasuk dalam jenis literatur, namun merupakan suatu media untuk mengakses informasi. Peneliti hanya ingin menunjukkan bahwa pemanfaatan informasi melalui internet berada pada peringkat ke tiga setelah skripsi. Cukup banyaknya sitiran digunakan bersumber dari internet dapat disebabkan luasnya pemanfaatan teknologi informasi untuk 
menyajikan informasi yang bermanfaat mendukung penulisan skripsinya.

Beragamnya penggunaan jenis literatur untuk penulisan skripsioleh mahasiswa Jurusan Kartografi dan Penginderaan Jauh ini, merupakan hal cukup baik yang menunjukkan bahwa mahasiswa mampu memanfaatkan berbagai jenis literatur yang tersedia.

Dominannya buku yang disitir, ternyata sesuai dengan ketersediaan buku yang memang lebih banyak disajikan/dimiliki di Perpustakaan Fakultas Geografi jika dibandingkan dengan jenis literatur lainnya. Hasil penelitian ini memperkuat hasil penelitian sebelumnya, yaitu penelitian Rustini dan Zulaikha bahwa dalam penulisan skripsi mahasiswa cenderung menggunakan jenis literatur buku.

\section{Bahasa literatur yang Disitir}

Hasil penelitian ini, ada 2 bahasa dalam literatur yang disitir yaitu bahasa Indonesia dan Bahasa Inggris. Mahasiswa Fakultas Geografi Jurusan Kartografi dan Penginderaan Jauh dalam penulisan skripsinya lebih banyak menggunakan literatur dalam bahasa Indonesia, hal ini terlihat pada tingginya penggunaan literatur berbahasa Indonesia yang mencapai $68,90 \%$. Pada tabel 2 sebanyak 794 sitiran $(31,10 \%)$ literatur yang disitir oleh mahasiswa dalam penulisan skripsi berbahasa Inggris. Penggunaan literatur yang berbahasa Indonesia lebih dominan, dapat pula dipengaruhi oleh kurangnya kemampuan mahasiswa dalam memahami bahasa Inggris.
Ketersediaan literatur yang Disitir di Perpustakaan Fakultas Geografi

Berdasarkan data sitiran yang digunakan dalam penulisan skripsi mahasiswa Jurusan Kartografi dan Penginderaan Jauh yang telah dicocokkan dengan data koleksi yang ada di Perpustakaan Fakultas Geografi diperoleh hasil bahwa sebanyak 1830 sitiran $(71,68 \%)$ tersedia di perpustakaan dan sebanyak 723 sitiran $(28,32 \%)$ tidak tersedia.

\section{Ketersediaan Buku}

Jenis literatur yang dominan digunakan dalam penulisan skripsi yaitu buku. Dari sebanyak 1686 sitiran jenis buku setelah dilakukan penghitungan, sebanyak 1122 buku yang disitir tersedia di perpustakaan dan 564 sitiran tidak tersedia di perpustakaan. Judul buku yang memiliki frekuensi sitiran tertinggi

\section{Tabel 4. Jurnal yang Disitir}

\begin{tabular}{|c|l|c|}
\hline Na. & \multicolumn{1}{|c|}{ Judul Jurnal } & $\begin{array}{c}\text { Frekuensi } \\
\text { Sitiran }\end{array}$ \\
\hline 1 & International Journal of Remote Sensing & 17 \\
\hline 2 & Duta Rimba & 10 \\
\hline 3 & Majalah Geografi Indonesia & 8 \\
\hline 4 & The Indonesia Journal Of Geography & 7 \\
\hline 5 & Photogrametric Enginering and Remote & \\
\hline 6 & sensing & 6 \\
\hline 7 & International Journal of Geographical & \\
\hline 8 & Warta Inderaja & 4 \\
\hline 9 & Fartography and GS & 4 \\
\hline 10 & Forum Geografi & 3 \\
\hline 11 & Geo-Informatika & 3 \\
\hline 12 & IEFE Trans on Geasciences and Remote & 3 \\
\hline 13 & Sensing & 3 \\
\hline 14 & $\ldots$ & 3 \\
15 & $\ldots$ & $\ldots$ \\
16 & $\ldots$ & $\ldots$ \\
46 & The Oriental Geographer & $\ldots$ \\
\hline
\end{tabular}


yaitu Penginderaan Jauh dan Interpretasi Citra ditulis oleh Lillesand, T.M. yang memperoleh 54 kali sitiran dan tersedia di perpustakaan. Diikuti buku berjudul Penginderaan Jauh Jilid 2 dan Penginderaan Jauh Jilid 1 keduanya ditulis oleh Sutanto, yang masing-masing memperoleh 50 sitiran dan 49 sitiran . Buku yang banyak memperoleh sitiran berarti buku tersebut penting bagi pemakai sehingga ketersediaannya di perpustakaan perlu diperhatikan.

\section{Ketersediaan Skripsi}

Skripsi merupakan jenis literatur yang banyak digunakan setelah buku (menduduki peringkat dua). Hal ini sesuai dengan kondisi Perpustakaan Fakultas Geografi dimana jumlah judul maupun eksemplar koleksi skripsi juga menduduki peringkat ke dua setelah buku. Skripsi yang disitir sebanyak 295 sitiran, 231 judul. Sebanyak 286 sitiran, terdiri atas 222 judul tersedia di perpustakaan dan 9 sitiran terdiri atas 9 judul tidak tersedia di perpustakaan. Skripsi yang tidak tersedia di perpustakaan berasal dari luar Fakultas Geografi, yaitu dari Fakultas Teknik UGM 4 judul, dari Fakultas Kehutanan Universitas Gadjah Mada 2 judul, dari Sekolah Tinggi Teknik Lingkungan 2 judul dan dari ITB 1 judul.

Hasil penelitian ini menunjukkan bahwa skripsi merupakan jenis koleksi yang dibutuhkan mahasiswa dalam kegiatan penelitian. Judul skripsi yang memperoleh sitiran tertinggi yaitu "Estimasi Produksi Daun Tembakau Berdasarkan Integrasi Pengolahan Citra Landsat Thematic Mapper dengan Sistem Informasi Geografis, Kasus sebagian Daerah Kabupaten Temanggung, oleh Sigit Herumurti.

\section{Ketersediaan Sumber Internet}

Kemajuan teknologi informasi semakin memberikan keleluasan bagi penulis ataupun peneliti untuk memperoleh informasi yang bersumber dari internet. Semakin banyaknya sumber referensi yang dapat diakses melalui berbagai website, dalam penyusunan skripsi mahasiswa memanfaatkan informasi yang bersumber dari internet.

Hasil penelitian ini pun menunjukan bahwa mahasiswa Jurusan Kartografi dan Penginderaan Jauh Fakultas Geografi UGM dalam penyusunan skripsinya menggunakan pula informasi yang bersumber dari internet. Kemungkinan bahwa sumber internet adalah sumber informasi yang tidak teredit dengan baik, sehingga diperlukan pemilihan informasi yang bersumber dari internet secara cermat. Informasi yang bersumber dari internet, dalam penulisan pada daftar pustaka, tidak hanya perlu disebutkan alamat websitenya, namun juga judul, tanggal dan jam diakses/diambil. Diperoleh sebanyak 138 sitiran yang bersumber internet. Perpustakaan Fakultas Geografi UGM memberikan jasa layanan internet, dengan demikian dalam penelitian ini sitiran yang bersumber internet ketersediaannya dapat dikatakan tersedia seluruhnya.

\section{Ketersediaan Jurnal/Majalah}

Hasil penelitian ini menunjukkan bahwa penggunaan jurnal/majalah menduduki peringkat ke empat setelah buku, skripsi dan sumber internet. Jurnal/majalah yang disitir sebanyak 115 sitiran. Hal ini dapat disebabkan lebih mudah memperoleh sumber referensi melalui internet dari pada jurnal/ majalah. Dapat pula disebabkan koleksi jurnal/ 
majalah di perpustakaan yang masih terbatas pada hasil tukar-menukar dengan jurnal yang diterbitkan oleh Fakultas Geografi UGM yaitu Indonesian Journal of Geography dan Majalah Geografi Indonesia. Dari 115 sitiran jumal yang digunakan mahasiswa Jurusan Kartografi dan Penginderaan Jauh, ditemukan 46 judul jurnal. Pada tabel 4 ditampilkan tiga belas besar jurnal berdasarkan peringkat perolehan sitiran

Jurnal yang memperoleh sitiran tertinggi adalah International Journal of Remote Sensing. Temuan dalam penelitian ini, sebagai bahan masukkan bagi perpustakaan untuk menyediakan jurnal-jurnal yang dibutuhkan pengguna. Dari 46 judul jurnal yang disitir tersebut yang tersedia di perpustakaan sebanyak 18 judul yang memperoleh 56 sitiran, sisanya 28 judul 59 sitiran tidak tersedia di perpustakaan.

\section{Ketersediaan Tesis}

Dari sebanyak 95 sitiran tesis yang digunakan mahasiswa dalam kegiatan penelitian, ditemukan 72 judul tesis. Sebanyak 6 judul masing-masing judul disitir sebanyak satu kali tidak tersedia di perpustakaan, dan sisanya 66 judul tersedia. Tesis yang tidak tersedia di perpustakaan merupakan tesis yang berasal dari luar Fakultas Geografi UGM. Walaupun tidak sebanyak penggunaan skripsi yang mencapai 284 sitiran, namun keberadaan tesis di perpustakaan memiliki arti penting. Oleh karena itu perpustakaan tetap mewajibkan mahasiswa yang telah menyelesaikan studi S2 untuk menyerahkan tesisnya ke perpustakaan. Judul tesis yang paling sering disitir adalah Penggunaan Foto Lldara untuk Mengetahui Kualitas Lingkungan Permukiman di Kodya Magelang dalam Hubungannya dengan Kondisi
Sosial Ekonomi Penghuni, yang ditulis oleh Noorhadi Rahardjo disitir sebanyak 5 kali.

\section{Ketersediaan Makalah}

Penelitian ini memperoleh 80 sitiran makalah terdiri 71 judul makalah dari 2553 sitiran dalam skripsi mahasiswa Jurusan Kartografi dan Penginderaan Jauh Fakultas Geografi UGM. Dari 80 sitiran, yang tersedia di perpustakaan sebanyak 16 sitiran terdiri atas 12 judul, sehingga 64 sitiran (59 judul) berupa makalah tidak tersedia di perpustakaan. Makalah memang belum dikoleksi secara khusus oleh Perpustakaan Fakultas Geografi UGM, hal ini dapat disebabkan oleh keterbatasan sumberdaya manusia yang dimiliki. Seperti kita ketahui bersama bahwa makalah bukan bahan yang dapat diperoleh dengan cara membeli, sehingga dibutuhkan peran aktif pustakawan untuk mendapatkaniıya.

\section{Ketersediaan Laporan Penelitian}

Laporan penelitian yang disitir sebanyak 51 sitiran terdiri atas 45 judul laporan penelitian, tersedia di perpustakaan sebanyak 19 judul, 24 sitiran. Susunan penelitian yang tidak tersedia di perpustakaan 26 judul, 27 sitiran. Tidak tersedianya laporan penelitian yang disusun oleh staf pengajar Fakultas Geografi UGM dapat disebabkan karena tidak adanya kewajiban bagi staf pengajar yang melaksanakan kegiatan penelitian untuk menyerahkan laporan penelitiannya ke perpustakaan.

\section{Ketersediaan Prosiding}

Prosiding yang disitir sebanyak 37 sitiran terdiri atas 21 judul. Sebanyak 16 judul, 32 sitiran prosiding tersedia di perpustakaan. 
Dengan demikian sebanyak 5 judul, 5 sitiran tidak tersedia di perpustakaan.

\section{Ketersediaan Surat Kabar}

Mahasiswa dalam kegiatan penelitian, terutama dalam menyelesaikan karya akhir skripsinya juga menggunakan sumber informasi yang berasal dari surat kabar. Dalam penelitian ini dihasilkan 26 sitiran surat kabar yang meliputi 3 surat kabar yaitu Kedaulatan Rakyat, Kompas dan Republika. Kedaulatan Rakyat dan Kompas tersedia di perpustakaan karena kedua surat kabar tersebut dilanggan oleh perpustakaan. Melihat kenyataan dua surat kabar yang dilanggan perpustakaan memperoleh sitiran yang cukup banyak, maka menurut pendapat penulis disitirnya kedua surat kabar tersebut, karena mahasiswa merasa mudah untuk memperolehnya di perpustakaan, disamping juga karena topiknya yang sesuai dengan skripsi yang dibahas. Republika tidak tersedia di perpustakaan, namun dalam penelitian ini Republika hanya mendapatkan satu kali sitiran. Berbeda dengan Kedaulatan Rakyat yang mendapat 13 kali sitiran dan Kompas 12 kali sitiran. Sehingga pemilihan langganan kedua surat kabar tersebut sudah cukup tepat.

\section{Ketersediaan Disertasi}

Hasil penelitian ini memperoleh 18 sitiran disertasi yang terdiri atas 7 judul. Keseluruhan disertasi yang disitir mahasiswa dalam penulisan skripsi tersedia di perpustakaan. Tersedianya seluruh disertasi yang disitir, menggambarkan bahwa perpustakaan telah baik dalam penyediaan jenis literatur ini, diharapkan dapat memberikan kepuasan kepada pengguna. Frekuensi sitiran tertinggi 9 kali disitir, yaitu disertasi Totok Gunawan yang berjudul Penerapan Teknik Penginderaan Jauh Untuk Menduga Debit Puncak Menggunakan Karakteristik Fisik Daerah Aliran Sungai.

Ketersediaan Laporan Praktek Kerja dan Pidato

Penelitian ini menemukan 13 sitiran terdiri atas 3 sitiran laporan praktek kerja dan 10 sitiran berupa pidato. Pidato yang memperoleh 3 sitiran adalah pidato guru besar Prof. Dr. Hadi Sabari Yunus, M.A. dan pidato Lektor yang disampaikan oleh Dr. Sunarto, M.S. Laporan praktek kerja yang tidak tersedia di perpustakaan merupakan laporan praktek kerja yang disusun oleh mahasiswa Fakultas Teknik Universitas Gadjah Mada, sehingga kemungkinan tersedia di perpustakaan Fakultas Teknik UGM. Sedangkan laporan praktek kerja yang disusun oleh Dwi Ari Wibowo berasal dari Fakultas Geografi UGM, sehingga tersedia di perpustakaan.

Hasil penelitian ini menunjukkan bahwa jumlah literatur yang disitir sebanyak 2554 sitiran, terdiri atas buku $66 \%$, skripsi $11,56 \%$, sumber internet $5,41 \%$, jurnal/majalah $4,51 \%$, tesis $3,72 \%$, makalah $3,14 \%$, laporan penelitian $2 \%$, proseding $1,42 \%$, surat kabar $1,02 \%$, disertasi $0,71 \%$ serta laporan praktek kerja dan pidato sebanyak 0,51\%.

Dari keseluruhan koleksi yang dipergunakan oleh mahasiswa dalam penulisan skripsinya, sebesar $71,68 \%$ tersedia di perpustakaan dan sebesar $28,32 \%$ tidak tersedia di perpustakaan. 


\section{SIMPULAN}

Penelitian yang telah dilakukan terurai diatas dapat disimpulkan hal-hal sebagai berikut, pertama jenis literatur yang digunakan sebagai sumber informasi bagi mahasiswa Jurusan Kartografi dan Penginderaan Jauh Fakultas Geografi UGM dalam penyusunan skripsi adalah buku, diikuti skripsi, sumber internet, jurnal/majalah, tesis, makalah, laporan penelitian, prosiding, surat kabar, disertasi dan laporan praktek kerja serta pidato. Kedua, bahasa literatur yang digunakan adalah bahasa Indonesia dan bahasa Inggris. Penggunaan literatur yang berbahasa Indonesia lebih dominan. Ketiga, setelah dilakukan pengecekan data sitiran dengan data koleksi di Perpustakaan Fakultas Geografi UGM ditemukan 1830 sitiran atau 71,68\% literatur yang disitir dalam penulisan skripsi tersedia di perpustakaan dan sebanyak 723 sitiran atau $28,32 \%$ literatur yang disitir tidak tersedia di perpustakaan.

\section{DAFTAR PUSTAKA}

Andriani, Juznia. 2002. "Studi Kualitatif Mengenai Alasan Menyitir Dokumen : Kasus pada Lima Mahasiswa Program Pascasarjana IPB". Dalam Jurnal Perpustakaan Pertanian, Volume 11, Nomor 2.

Arikunto, Suharsimi. 2002. Prosedur Penelitian: Suatu Pendekatan Praktek. Jakarta : PT Rineka Cipta.

Echols, John M. dan Hassan Shadily. 1989. Kamus Inggris Indonesia. Jakarta : Penerbit PT Gramedia.
Fakultas Geografi. 2005. Pedoman Penulisan Usulan Penelitian E Skripsi. Yogyakarta : Fakultas Geografi UGM.

Gooden, Angela M. 2001. "Citation Analysis of Chemistry Doctoral Dissertations An Ohio State University Case Study". Dalam http://www.library.ucsb.edu/istl/01-fall/ refereed.html, tanggal 31 Agustus 2005, pukul 12.35 .

Ramesh, L.S.R.C.V. and A.V.S.S. Nagaraju. 2000. "Citation Analysis of the Indian Journal of Information, Library and Society". Dalam Indian Journal Information Library E Society, Volume 13 , Nomer 3-4.

Reitz, Joan M. "ODLIS- Online Dictionary for Library and Information Science". Dalam http://lu.com/odlis/odlis c.cfm, tanggal 07 Februari 2006, pukul 15.30.

Riduwan. 2004. Metode E Teknik Menyusun Tesis. Bandung : Alfabeta.

Rupadha, I Komang. 1996. "Kajian Analisis Sitiran terhadap Laporan Penelitian Dosen Universitas Mataram (Suatu Kajian Perbandingan Analisis Sitiran Antara Laporan Penelitian Dosen Fakultas Hukum, Ekonomi, Pertanian dan Peternakan Periode Tahun 1991-1995)" ( Proposal Seminar Pra Tesis). Program Pascasarjana, Universitas Indonesia Jakarta.

Rustini. 2003. "Karakteristik Literatur yang Disitir dalam Skripsi Fakultas Psikologi UI dari Tahun 1998-2002" (Skripsi). Program Studi Ilmu Perpustakan UI, Jakarta.

Septiyantono, Tri dan Umar Sidik. 2003. DasarDasar Ilmu Perpustakaan dan Informasi. Yogyakarta : Jurusan Ilmu Perpustakaan 
dan Informasi, Fakultas Adab UIN Sunan

Kalijaga Yogyakarta.

Sugiyono. 1993. Metode Penelitian Administrasi.

Bandung : Alfabeta.

Sulistyo-Basuki. 2002. "Bibliometrik, Sainsmetrik dan Informetrika". Dalam Makalah untuk Kursus Informetrika, diselenggarakan oleh Masyarakat Informetrika Indonesia, 20 s.d. 23 Mei 2002.

Sulistyo-Basuki. 2006. Pengantar Ilmu Perpustakaan dan Informasi. Dalam Proses Penerbitan.(Rekayasa Sains).

Surata, I Gede. 1997. "Karakteristik Literatur yang Disitir dalam Skripsi Jurusan Ilmu Politik Fakultas Ilmu Sosial dan Ilmu Politik Universitas Hasanuddin dan Universitas Indonesia Tahun 1991-1995" (Tesis). Program Pascasarjana Universitas Indonesia, Jakarta.

Sutardji. 2003." Pola Sitiran dan Pola Kepengarangan pada Jurnal Penelitian Tanaman Pangan". Dalam Jurnal Perpustakaan Pertanian, Volume 12, Nomor 1.

Yulia, Yuyu. 1995. "Karakteristik Literatur yang Disitir dalam Disertasi Bidang Agronomi Tahun 1981-1990" (Tesis). Program Pascasarjana, UI Jakarta.

Zulaikha, Sri Rohyanti. 2002. "Kajian Analisis Sitasi terhadap Skripsi Mahasiswa IAIN Sunan Kalijaga di UPT Perpustakaan IAIN Sunan Kalijaga Yogyakarta (Suatu Evaluasi Keterpakaian Koleksi Perpustakaan Ditinjau dari Analisis Sitasi)"(Tesis). Program Pascasarjana, UGM Yogyakarta. 